\title{
Religiozno iskustvo s motrišta transcendentalne refleksije i njegova uloga spram kritika metafizike i dokaza za Božje postojanje
}

\author{
Anto Pavlović* \\ apavlovic2010@gmail.com \\ Stjepan Štivić** \\ stjepan.stivic@gmail.com
}

UDK: 231.11

UDK: 231.11

Izvorni znanstveni rad / Original scientific paper

Primljeno: 23. lipnja 2017.

Prihvaćeno: 13. srpnja 2017.

Može li se tradicionalnim dokazima za Božje postojanje još uvijek pristupati tako da se značajnije ne uzimaju u obzir niti one kritike koje ozbiljno dovode u pitanje metafiziku, a time i dokaze, kao ni moguća uloga nekog oblika religioznog iskustva spram tih kritika? U članku problematiziramo to pitanje, donoseći i analizirajući nekoliko uvida za koje držimo da mogu pridonijeti ispravljanju manjkavosti takvog pristupa. To činimo iz jedne specifične perspektive koju, prema njezinoj filozofskoj podlozi, nazivamo transcendentalno-refleksivna. Nastojimo pokazati da ta perspektiva: a) daje drukčiji pogled na klasičnu metafiziku, a time i na dokaze; b) očituje da je u same temelje spontanog ljudskog životnog iskustva, kroz su-iskustvo Punine Bitka-Temelja-Sveobuhvatnog Smisla, iskonski $i$ intimno utkana jedna religiozna crta, što metafizici, a onda $i$ tradicionalnim dokazima utemeljenim na njezinim kategorijama, daje zbiljski sadržaj, a time i stvarnu snagu spram kritika. Analize također iznose na vidjelo specifičnost religioznog iskustva na koje upućuje transcendentalna refleksija; ono nije samo privilegij ljudi koji pripadaju nekoj religiji ili slijede neko posebno vjerovanje, nego pripada čovjeku kao čovjeku, vezano je dakle, kao i dokazi, uz njegovu duhovnu, tj. racionalnu strukturu.

Ključne riječi: metafizika, dokazi za Božje postojanje, transcendentalna refleksija, konkretno životno iskustvo, religiozno iskustvo.

\footnotetext{
* Doc. dr. sc. Anto Pavlović, Fakultet filozofije i religijskih znanosti Sveučilišta u Zagrebu, Jordanovac 110, HR-10000 Zagreb.

** Stjepan Štivić, mag. fil., doktorand na Fakultetu filozofije i religijskih znanosti Sveučilišta u Zagrebu, Jordanovac 110, HR-10000 Zagreb.
} 


\section{Uvod}

Uvidom u građu iz područja filozofske teologije, posebice u onaj dio koji se izravno odnosi na tradicionalne dokaze za Božje postojanje ${ }^{1}$ - riječ je dakle o različitim manualima, udžbenicima i drugoj relevantnoj literaturi, uglavnom skolastičke inspiracije, kako na hrvatskom tako i na drugim jezicima - zanimljivo je primijetiti da se tim dokazima, uz malobrojne iznimke, još uvijek pristupa, tj. uzima ih se, proučava i poučava, kao da se, govoreći pojednostavljeno, od vremena Tome Akvinskog do danas u povijesti filozofije nisu dogodile značajnije promjene. To se prvenstveno ogleda u činjenici da se vrlo malo uzimaju u obzir i one kritike koje ozbiljno dovode u pitanje klasičnu metafiziku², čije su kategorije u samom temelju racionalnog dokazivanja Božjeg postojanja. Već je od Kanta razvidno da je kritika metafizike ujedno i kritika racionalne teologije, odnosno teoretskog dokazivanja Božjeg postojanja. Osim toga, to se također pokazuje i u činjenici da se u pristupu dokazima, dakle u kontekstu njihova razlaganja i obrane njihove dokazne snage, još uvijek ne uzima značajnije u obzir religiozno iskustvo, kao jedna od eminentnih tema suvremene filozofije, niti se s naročitom pozornošću razmatra pitanje njegove moguće uloge spram kritika. $^{3}$

Ako se, unatoč kritikama, želi sačuvati nekompromitiranim zbiljski sadržaj i stvarna snaga tradicionalnih logičko-spekulativnih dokaza za Božje postojanje, držimo da je priziv na religiozno iskustvo, ili barem na neki njegov vidik, put koji je danas filozofski neopravdano ignorirati. U tom smislu J. Ćurić piše:

»Za racionalno uspinjanje Bogu, odnosno za formuliranje solidnih dokaza o Božjoj opstojnosti neminovan je preduvjet; da ispravno zagledamo ishodišnu točku svog argumentiranja - od Boga dano religiozno iskustvo. «

\footnotetext{
${ }_{1}$ Tu prvenstveno mislimo na one dokaze koje Toma Akvinski sažima u "pet puteva (usp. Summa Th., l, q. 2, a. 3), strukturirajući ih na temelju misaone baštine svojih predšasnika i dajući im novu dimenziju u skladu s vlastitim metafizičkim uvidima, kao i na različite inačice tih dokaza kroz povijest.

2 Prije svih, po važnosti i utjecaju, tu mislimo na Kantovu kritiku, ali i na one iz 20. st., poput logičkog pozitivizma i Heideggerova prigovora o »zaboravu bitka«, centralnom točkom njegova kapitalnog djela Sein und Zeit.

${ }^{3}$ Od desetak priručnika-knjiga iz područja »filozofske teologije« koje se mogu naći na hrvatskom jeziku, u pristupu dokazima, samo njih nekoliko, i to uglavnom uzgred, uzima u obzir ta pitanja. Npr. Vilim Keilbach, u Problem Boga u filozofiji, donosi vrlo kratak i više generalan osvrt na Kantove kritike metafizike i dokaza. Ivan Devčić, u Bog i filozofija, predstavlja kratak pregled kritika iz 20. st., s naglaskom na logički pozitivizam i egzistencijalizam. Stjepan Kušar, u Filozofija o Bogu, jedno kratko poglavlje posvećuje religioznom iskustvu. I to je uglavnom sve. Zanimljivo je, na istom tragu, primijetiti da je posljednjih tridesetak godina, na katoličkim učilištima u SAD-u, jako poraslo zanimanje za filozofiju Tome Akvinskog, posebice za proučavanje puteva za Božje postojanje. No i tu se ogleda ista tendencija: iz pojedinih njegovih djela uzimaju se tekstovi koji obrađuju ta pitanja, analizira ih se, ali bez značajnijih pokušaja da se uzmu u obzir i kritike.

${ }^{4}$ Josip ĆURIĆ, »Dokazivanje Božje opstojnosti nekoć i danas«, u: Tomizam nekoć i danas, Zagreb, 2003, 153.
} 
U radu se želi ukratko razmotriti ta pitanja, čiju se iskonsku nutarnju povezanost kani pokazati u specifičnom pristupu koji se razvio na tragu transcendentalne filozofije. Uz uvod i zaključak, rad je strukturiran u četiri dijela. Prvi dio je više propedeutskog karaktera. U njemu je ukratko naznačen misaoni okvir i perspektiva iz koje se kani pristupati problematici, što će dati ključ za njezino praćenje i razumijevanje.

Budući da su klasična metafizika i dokazi za Božje postojanje u odnosu specifične nutarnje povezanosti, razlaganje započinjemo upravo od tog odnosa, s prizivom na metodu refleksije koja je, kako će se u analizama pokazati, imanentna klasičnoj filozofiji-metafizici, ali i integralan dio transcendentalne filozofije.

Uvide do kojih se dođe na metafizičkoj razini, razmatrat će se u sljedećem koraku upućujući na njihove ekvivalente $u$ iskustvenom redu. Tu se želi pokazati da ono što dadnu analize konkretnoga životnog iskustva, upućuje zapravo na ishodišnu točku, a time i na zbiljski sadržaj i stvarnu snagu spekulativnih dokaza za Božje postojanje. S tim ciljem, u refleksiji transcendentalnog karaktera nastojat će se otkriti je li u cjelovitost ljudskog spontanog životnog iskustva već iskonski i intimno utkana neka religiozna crta, odnosno očituje li se, u sveukupnosti ljudskog životnog iskustva, na nekoj razini i pod nekim vidikom, prisutnost Uzvišenoga, Svetoga, Boga? Da bi se odgovorilo na to pitanje, analizirat će se, u glavnim linijama, ljudsko konkretno životno iskustvo i to iz perspektive njegovih dvaju osnovnih područja: prvo se nazva transcendentalno iskustveno područje, koje je po svojoj naravi dio filozofske refleksije, dok je drugo područje izravnoga, tj. spontanoga svakodnevnog životnog iskustva, koje je blisko svakom čovjeku, bavio se on filozofijom, tj. filozofskom refleksijom, ili ne. ${ }^{5}$

Naposljetku se ukratko osvrće na samu riječ - pojam - Bog. Ona se u ovom kontekstu redovito koristi tako da se ne dovodi u pitanje niti posebno propituje opravdanost njezine uporabe. No, kao i tradicionalni dokazi, njezina je uporaba danas, na tragu logičkog pozitivizma i filozofije jezika, postala predmetom osporavanja i kritika. Stoga se, na istoj liniji, tj. koristeći metodu refleksije, želi ukratko naznačiti ulogu religioznog iskustva u legitimiranju njezine, pa i filozofske, uporabe. Dobar dio ideja koje su naznačene, zbog prostornoga ograničenja, ostaje u naznakama, ali s dovoljno jasnim usmjerenjima.

\footnotetext{
${ }^{5}$ Ovdje, kako se već primjećuje, ne kanimo se baviti iznimno širokim područjem i brojnim aspektima fenomena religioznog iskustva, o kojem je, u okviru suvremene filozofije, $u$ širem kontekstu filozofije religije, zaista puno pisano. Cilj nam je u refleksiji transcendentalnog karaktera doprijeti do samih temelja ljudskog iskustva, do onog iskustva koje je uvjet mogućnosti svakog drugog iskustva, te pokazati njegov religiozni karakter kao i njegovu iskonsku bliskost s najdubljim metafizičkim uvidima koji vode do Onoga koji je Ipsum Esse.
} 


\section{Misaoni okvir}

Uvodne naznake, koje govore u terminima »uvjet mogućnosti«, bilo da je riječ o metafizičkom kontekstu ili onom koji se odnosi na iskustvo, upućuju na misaoni okvir u kojemu ćemo se kretati i koji će biti u podlozi naših analiza: riječ je dakle $o »$ transcendentalnoj filozofiji«. Preciznije, pristup, odnosno perspektivu koju ćemo ovdje slijediti, možemo nazvati »transcendentalno-refleksivnom«. Idejni joj je začetnik belgijski isusovac Joseph Maréchal (1878-1944).

Zanimljivost i originalnost Maréchalova pristupa jest $u$ tome da je, $u$ vremenu koje možemo nazvati post-kantovsko, bio prvi među pobornicima klasične metafizike - riječ je dakle uglavnom o autorima skolastičke inspiracije - koji Kanta nije držao njezinim »neprijateljem« $\mathrm{i} »$ rušiteljem«, kojega treba ili ignorirati ili protiv kojeg se treba boriti, nego, naprotiv, promišlja klasičnu metafiziku, prvenstveno onu Tome Akvinskog, uzimajući u obzir njegovu kritiku i usvajajući njegovu transcendentalnu metodu. ${ }^{6}$

Maréchal, na Kantovu tragu, polazi od spoznajno-teoretskog aspekta problema. Prihvaća njegovu transcendentalnu metodu, ali pokazuje da Kant tom metodom, doduše, dohvaća univerzalni i nužni, ali ipak samo formalni $a$ priori spoznaje, te time, tvrdi Maréchal, ne koristi cjeloviti potencijal koji ta metoda pruža. ${ }^{7}$ Tragom te iste metode, Maréchal ide korak dalje, pokazujući da svaki formalni a priori zahtijeva drugi a priori iz ontološkog reda, što se, prama nje$\mathrm{mu}$, jasno ogleda u svakom sudu egzistencije. ${ }^{8}$ Osnovni cilj Maréchalova nastojanja jest nanovo »udahnuti život« metafizici bitka da bi na toj podlozi mogao otvoriti nov prostor racionalnoj teologiji. ${ }^{9}$

Maréchalov pristup slijedili su i dalje razvijali mnogi suvremeni mislioci, posebno među isusovcima..$^{10} \mathrm{U}$ domaćem znanstvenom okružju, ovaj pristup, unatoč filozofski vrijednim uvidima, nije uhvatio dubljih korijena. Nešto više pozornosti, u smislu transcendentalno-refleksivnog pristupa religioznom iskustvu i njegove uloge u sadržajnom osnaživanju tradicionalnih dokaza za Božje postojanje spram suvremenih kritika, posvetio je isusovac Josip Ćurić, dugogodišnji profesor filozofije na Katoličkom bogoslovnom fakultetu u Zagrebu. U

\footnotetext{
${ }^{6} \mathrm{~J}$. Maréchal te ideje razvija u svom kapitalnom djelu: Le point de départ de la métaphysique, koje je od 1922-1949 izašlo u pet svezaka.

7 Usp. Joseph MARÉCHAL, C. III: La Crique de Kant, Bruges, 1923.

8 »Si l'on accepte le donné phénoménal [...], on accepte du même coup, et forcément, tout ce qui est logiquement indispensable pour rendre ce donné simplement intelligible, c'est-à-dire possible. La chose en soi est réelle comme condition de possibilité du phénomène, ni plus ni moins « (Joseph MARÉCHAL, C. III: La Crique de Kant, 217).

${ }^{9}$ Usp. Joseph MARÉCHAL, C. V: Le thomisme devant la philosophie critique, Paris, 1949.

${ }^{10}$ Jedan od istaknutih neo-tomista J. B. Metz, govoreći o »suvremenom tomizmu« inspiriranom na idejama J. Maréchala, navodi sljedeća imena - na francuskom govornom području: P. Rousselot, A. Marc i J. de Finance, te na njemačkom: J. B. Lotz, M. Müller, K. Rahner, G. Siewerth, B. Welte (usp. Johann Baptist METZ, Christliche Anthropozentrik. Über die Denkform des Thomas von Aquin, München, 1962, 127).
} 
radu ćemo se ponajviše oslanjati na njegove uvide. Osim Ćurićevih, uzet ćemo u obzir i pojedine ideje druge dvojice isusovaca koji su, svaki na svoj način, slijedili Maréchalovu misao: riječ je o francuskom filozofu Josephu de Financeu i poznatom njemačkom filozofu i teologu Karlu Rahneru.

\section{Je li metafizika samo »igra« riječi bez sadržaja i značenja?}

Kako je u uvodu naznačeno, potrebno je ovdje krenuti od metafizike iz jednostavnog razloga što su njezini pojmovi i kategorije temeljna »poluga« $u$ strukturi spekulativnih dokaza za Božje postojanje. To ujedno znači da se slabosti i problemi metafizike posljedično reflektiraju i na racionalnu teologiju.

Činjenica je da klasična metafizika, već s Kantovom kritikom, a posebice u kontekstu suvremene filozofije, nailazi na ozbiljna osporavanja. S jedne strane, odriče joj se mogućnost dohvaćanja bitka, dok joj se s druge strane spočitava da svoje kategorije previše uzima i misli isključivo iz perspektive objekta, tj. pomoću objektivnih shema, čime zanemaruje subjekt i njegovu ulogu, ali gubi iz vida i zanemaruje ono što bi trebao biti u stalnom fokusu njezine pozornosti; to je činjenica postojanja, »bitak«. Da ti prigovori nisu bez osnova primjećuje J. de Finance:

»Na Aristotelovoj liniji ‘biće' (postojanje n.a.), biva razumijevano polazeći od objekta, shvaćenog kao res sensibilis, iz čega proizlazi određena tendencija objektivacije stvarnosti, tj. pretvaranja stvarnosti u stvari, koja rezultira opasnošću da se zanemari vlastita vrijednost ljudskog duha, kao i uloga vlastita subjektu [...] (zanemaruje se subjektivni aspekt stvarnosti - n. a.).«11

U odgovoru na te kritike, kao prvi korak, držimo potrebnim osvrnuti se ukratko na pitanje razumijevanja pojma »bitka« u klasičnoj metafizici. Smatramo da je to ključno pitanje, kako za metafiziku tako i za tradicionalne dokaze, jer »bitak« je stožerni pojam metafizike, a ujedno i »šifra« za racionalno uspinjanje Bogu. Cilj je dakle vidjeti koliko su ti prigovori opravdani i mogu li i dalje metafizički pojmovi i načela biti korišteni kao pouzdan oslonac spekulativnim dokazima za Božje postojanje.

Upozoravajući na opasnost objektivacije stvarnosti, a time i zanemarivanja bitka i subjekta, čije se tendencije očituju na Aristotelovoj liniji tumačenja pojma »biće kao biće«, de Finance naglašava da »toj opasnosti Toma Akvinski izmiče zahvaljujući svom izvanrednom geniju« ${ }^{12}$ Genijalnost o kojoj de Finance tu govori odnosi se zasigurno na originalan doprinos Tomine metafizike $u$

\footnotetext{
${ }^{11}$ „Seulement, en dépendance d'Aristote, cet être est conçu à partir de l'objet, de la res sensibilis, d'où une certaine tendance au chosisme, avec danger de méconnaître la valeur propre de l'esprit et la fonction propre du sujet, [...] « (Joseph de FINANCE, Connaissance de lêtre. Traité d'Ontologie, Paris-Bruges, 1966, 12).

$12 »[\ldots]$ danger auquel saint Thomas n'échappe que par son exceptionnel génie« (isto, 12).
} 
shvaćanju pojma »bitka«. Tu se zapravo pokazuje ključna razlika između Tomine i Aristotelove metafizike, jer Toma izlazi iz sjene Aristotelova tumača, kako je bio često nepravedno percipiran, i potvrđuje svoju originalnost. Dok se Aristotel, promišljajući »biće kao biće«, zaustavlja na formi, na »formalnom aktu« bića, Toma, ide korak dalje, usmjerujući svu pozornost svoje metafizike na "actus essendi« (djelatni čin bivstvovanja), ne zanemarujući dakako ni objektivan aspekt stvarnosti. Zamijeniti, stoga, ili poistovjetiti Tomin »djelatni akt (čin) bivstvovanja« s Aristotelovim »formalnim aktom«, bila bi krupna pogreška, jer iz te razlike proizlaze iznimno važne implikacije, kako za samu metafiziku, tako onda posljedično i za tradicionalne dokaze za Božje postojanje. ${ }^{13}$

J. de Finance, u suglasju s Gilsonom, drži da iz cjeline filozofske-metafizičke misli Tome Akvinskog jasno proizlazi da jedino autentično tumačenje pojma bitka u njegovoj metafizici može biti ono koje u njemu vidi actus essendi, tj. djelatan čin, kojim svako pojedinačno biće bivstvuje - jest. Bitak, prema ovom shvaćanju, nije ni stvar niti ideja, nego obuhvaća sve, čineći ontološku konzistenciju stvari, te dajući ontološki status, to jest objektivnost idejama. Tako shvaćen, »bitak« se ne može uzeti ni kao predikat niti kao atribut, jer je on iskonski izvor i ontološki uvjet mogućnosti svake predikacije i svake atribucije. ${ }^{14}$

$\mathrm{Na}$ tragu takvog shvaćanja pojma »bitka« - »actus essendi« (djelatan čin bivstvovanja) - klasična metafizika, da bi izbjegla vlastitu »mortifikaciju«, a time i otklonila prigovore i kritike, pozvana je biti trajno usmjerena na svoju temeljnu zadaću, tj. biti u stalnoj relaciji, biti bez prestanka usmjerena na tu primordijalnu činjenicu postojanja, »bitak«, promišljajući je iz perspektive pitanja: što treba reći o bilo kojem pojedinačnom biću zbog same činjenice da jest, da postoji? U ostvarivanju te zadaće, metafizika je upućena na »metodu refleksije«,

${ }^{13}$ Poznati francuski neo-tomist É. Gilson, jedan od najzaslužnijih za rasvjetljavanje autentičnog tumačenja pojma bitka u metafizici Tome Akvinskog, ističe: »S. Thomas admire Platon et Aristote de s'être élevés jusque-là. Ce n'est pourtant pas tout, car une fois expliqué pourquoi un étant est ce qu'il est, il reste à expliquer ce qui fait qu'il existe« (Étiene GILSON, Le thomisme. Introduction à la philosophie de S. Thomas d'Aquin, $6^{\circ}$ re., Paris, 1965, 173).

${ }^{14}{ }$ Glavni vidik tomizma, želim reći onog autentičnog, jest zasigurno vidjeti u djelatnom činu bivstvovanja temeljnu metafizičku vrijednost, to jest savršenost svake savršenosti« (Joseph de FINANCE, Connaissance de lêtre. Traité d'Ontologie, 52). Evo nekoliko tekstova iz različitih djela Tome Akvinskog koji potvrđuju tu tezu:

"Omnis enim nobilitas cujuscumque rei est sibi secundum suum esse" (Summa contra Gentiles, I, 28);

»Esse est inter omnia perfectissimum [...]. Unde patet quod hoc quod dico esse est actualitas omnium actuum et propter hoc est perfectio omnium perfectionum «(De Potentia, q. 7, a. 2, ad 9). »Ipsum esse est perfectissimum omnium; nihil enim habet actualitatem nisi in quantum est; unde ipsum esse est actualitas omnium rerum et etiam ipsarum formarum « (Summa Th., I, q. 4 , a. 1, ad 3 ).

U metafizici, koja »bitak« shvaća na takav način, ne može se govoriti o njegovu zanemarivanju ili »zaboravu«. U to smislu de Finance primjećuje: »Il est étrange que Heidegger s'obstine à voir dans l'abstraction du Sein par la philosophie traditionnelle une abstraction de même type que celle des universaux, ce qui réduit l'être, selon lui, á un concept « (De Finance, Connaissance de l'être. Traité d'Ontologie..., 32). 
koja je, kako će se u analizama pokazati, imanentna klasičnoj metafizici, ali je i ključna sastavnica transcendentalne filozofije.

Što dakle metafizika, a onda posljedično i racionalna teologija, dobivaju slijedeći metodu refleksije transcendentalnog karaktera? U odgovoru na to pitanje izaći će na vidjelo i sama narav te refleksije.

Temeljna je zadaća refleksije da kontinuirano usmjerava metafiziku da u pristupu stvarnosti polazi od čovjeka u konkretnosti njegova življenja. Ili još preciznije, da polazi od dinamizma ljudske duhovne, tj. misaone aktivnosti kakva se očituje u njegovu konkretnom življenju. U tom se dinamizmu očituje kako čovjek refleksivno dohvaća činjenicu postojanja, i to ukoliko je on sam biće po posjedovanju bitka, te ukoliko, budući da je duhovno biće, živi u stalnoj relaciji, tj. otvorenosti prema bitku, prema svemu što se nalazi na obzoru bitka, te naposljetku, ili, možda ispravnije je reći, prije svega, prema Bitku u punini kao Temelju. Tu dolazimo do nekoliko važnih uvida:

Nalazimo »rehabilitiranu« ulogu subjekta. Štoviše, pokazuje se da je refleksija imanentna samoj ljudskoj duhovnoj - misaonoj - aktivnosti.

Refleksija iznosi na vidjelo da je upravo »bitak-činjenica postojanja« uvjet mogućnosti, tj. ono što vodi i upravlja cjelokupnu ljudsku »duhovnu-misaonu« aktivnost.

Zadaća koju ona stavlja pred metafiziku jest da neprestano usmjeruje svu svoju pozornost na »bitak-činjenicu postojanja«, nadilazeći ono što se nudi izravno, to jest sve eventualne pojedinačne izričaje, odnosno određenja - quidditas - bitka.

$\mathrm{Na}$ taj način, refleksija ne dopušta metafizici da se »izgubi« isključivo u formalnom aspektu stvarnosti, što bi vodilo njezinoj »mortifikaciji«, a time i nemogućnosti racionalne teologije, nego je stalno upućuje prema onoj Zbilji koja je uvjet mogućnosti svake druge zbiljnosti. U tom smislu ovu refleksiju možemo nazvati i »metafizičkom«.

Kao što se već jasno naslućuje, krajnji cilj na koji metafizička refleksija transcendentalnog karaktera upućuje jest ne dopustiti da se, u težnji za uvijek dubljim i potpunijim razumijevanjem stvarnosti, zaustavimo dok ne dohvatimo odgovor na onaj zašto, koji je u apsolutnom smislu uvjet mogućnosti svakog drugog zašto, odnosno poslije kojega svaki drugi zašto više nema smisla. ${ }^{15}$

Razvidno je da pristup stvarnosti metodom transcendentalne refleksije, osigurava pojmovima i načelima klasične metafizike neko sasvim drukčije, primjerenije, tj. sadržajno dublje i plodnije određenje. »Bitak-postojanje«, u metafizičkoj refleksiji transcendentalnog karaktera, pokazuje se, s jedne strane, već prisutnim $\mathrm{u} » d n u$ « čovjekove iskustvene svijesti kao njegov ontološki temelj, te s druge, ujedno i istovremeno, kao »svjetlo« koje ljudski duh slijedi u transcendiranju samoga sebe, na putu propinjanja k onom Bitku koji je, kako će se sada u analizama ljudskog konkretnog iskustva pokazati, Temelj i Sveobuhvatni Smisao.

\footnotetext{
${ }^{15}$ Usp. Joseph de FINANCE, »Être et subjectivité«, Personne et valeur, Rim, 1992, 22.
} 


\section{Konkretno životno iskustvo potvrđuje i sadržajno osnažuje metafizičke uvide}

Uvide do kojih smo došli u metafizičkoj refleksiji, sada ćemo analizirati promišljajući ih iz perspektive konkretnog životnog iskustva. Nastojat ćemo najprije pokazati da dostignuća iz metafizičkog reda izravno upućuju na srodnu iskustvenu podlogu, odnosno na ekvivalente u konkretnom iskustvu, a zatim, da ta iskustvena podloga istovremeno upućuje na zbiljski sadržaj i stvarnu snagu logičko-spekulativnih dokaza za Božje postojanje.

Pitanje od kojega tu polazimo i nad kojim želimo reflektirati jest sljedeće: dohvaćamo li, u sveukupnosti ljudskog životnog iskustva, na nekoj razini i pod nekim vidikom, prisutnost Uzvišenoga, Svetoga, Boga? Nastojat ćemo dakle ispitati, je li u cjelovitost ljudskog spontanog životnog iskustva, ipak iskonski i intimno utkana neka religiozna crta? Da bi se to moglo učiniti, razmotrit ćemo, u glavnim linijama, ljudsko životno iskustvo, i to iz perspektive njegovih dvaju osnovnih područja: prvo ćemo nazvati transcendentalnim, ne tematskim iskustvenim područjem, koje je već po svom karakteru dio filozofske refleksije, dok je drugi vidik područje konkretnog, spontanog životnog iskustva koje je pak blisko svakom čovjeku, bavio se filozofijom, tj. filozofskom refleksijom ili ne.

Budući da s pomoću transcendentalne refleksije nastojimo pokazati iskonsko jedinstvo onoga što se dostiglo na metafizičkoj razini, s onim na što upućuju analize konkretnog ljudskog životnog iskustva, i ovdje ćemo slijediti tu istu metodu.

\subsection{Transcendentalno iskustveno područje - iskustvo Temelja}

Sam pojam »transcendentalno« upućuje na polje životnog iskustva koje prethodi i omogućuje filozofsku refleksiju: svaki pokret ljudskog intelekta i volje nastaje iz tog iskustva. Ipak, istodobno ono sâmo ostaje uvijek u pozadini kao u sjeni, netematizirano. Tek pozornim reflektiranjem moguće je dohvatiti $\mathrm{i}$ iskazati nešto od tog bogatog sadržaja koji je stalno prisutan u dubini ljudske svijesti. Refleksijom tu primarno nastojimo tematizirati, tj. iznijeti na vidjelo: što zapravo sve mislimo kad bilo što mislimo, što sve hoćemo kad bilo što hoćemo, odnosno što je sve, na različitim razinama, uključeno i pretpostavljeno $u$ bilo kojem pojedinačnom pokretu našeg intelekta i naše volje?

Uviđamo, dakle, da se, dok govorimo o najobičnijim stvarima i događajima, poput sunca, kiše, ljudi... iza toga, u dubini naše svijesti, kao uvjet mogućnosti tog govora, ali i svakog drugog govora, na različitim razinama, krije mnoštvo neizrečenih, tj. netematiziranih uvida.

Privi i temeljni uvid jest da stvarnost postoji, da je u sebi smislena, te da je, kao takva, dostupna intelektu i volji, tj. dohvatljiva je našoj spoznaji i iskustvu. 
Istovremeno uviđamo da se kroz tu stvarnost suvereno krećemo, što znači da kod svakog svjesnog i slobodnog čina iskustveno doživimo da nismo zatvoreni u vlastitoj subjektivnosti, niti da nas »svijet« može »zatvoriti« u svoje okvire. Naprotiv, iskustveno doživljavamo da smo bića ontološki slobodna, od nosno iskonski otvorena prema svemu što je na obzoru bitka, te naposljetku, ili prije svega, prema Bitku u punini, kao ontološkom Temelju cjelokupne stvarnosti. ${ }^{16}$

Pokazuje se također, da je ta relacija s Temeljem, zbog njezina konstitutivnog karaktera, jedina obilježena nužnošću. ${ }^{17}$ Sve druge relacije s pojedinačnim bićima subjekt bira, ali uvijek i nužno s podloge Temelja-Totaliteta. To znači da je tek s podloge Punine Bitka-Temelja moguće iskustveno dohvatiti i afirmirati egzistenciju pojedinačnih bića. Što opet posljedično znači da je u svakom pojedinačnom činu iskustva i u pojedinačnoj afirmaciji, tj. $u$ iskustvu i afirmaciji pojedinačnih, ograničenih bića, istovremeno na implicitan način uključen, to jest su-afirmiran i su-iskušen sam Temelj, Punina Bitka. ${ }^{18}$ Te da u svakoj protegnutosti našega duha prema bilo kojem pojedinačnom biću, mi zapravo težimo i usmjereni smo prema Punini Bitka, Temelju. ${ }^{19}$

Na tragu iznesenoga može se reći da je kod transcendentalnog iskustva prije svega riječ o tematizaciji i eksplikaciji, sada na konkretnoj iskustvenoj razini, istih onih uvida do kojih smo prethodno došli u metafizičkoj refleksiji. U transcendentalnom iskustvu, kako se primjećuje, nije riječ o izravnom iskustvu Boga, nego je tu čovjek upućen prema Njemu, tj. zaziva ga kroz refleksivnu otvorenost svoga duha prema Beskraju, koji je Punina i Temelj. Tu dakle čovjek živi i iskustveno dohvaća svoju unutarnju usmjerenost prema Punini-Temelju, ili ako želimo prema Bogu kao Cilju. ${ }^{20}$ Iako, dakle, tu nije riječ o izravnom iskustvu Boga, ipak takvoj vrsti iskustva teško se može zanijekati svojevrstan religiozni karakter.

\footnotetext{
${ }^{16}{ }$ Čovjek je ograničeno biće smješteno u materijalni svijet, ali istodobno otvoreno prema Neizmjernom i Bezgraničnom" (Karl RAHNER, Selbsterfahrung und Gotteserfahrung. Schriften zur Theologie, sv. X, Einsiedeln, 1972, 133-145, 133).

${ }^{17}$ Rahner to sažima na sljedeći način: „Čovjek je duh, tj. živi svoj život u neprestanoj težnji, otvorenosti prema Bogu. Ta otvorenost nije neki događaj koji bi se već prema čovjekovoj želji mogao zbiti ili ne, nego je temeljni uvjet mogućnosti koji čini ljudsko biće onim što jest i što treba biti, te je prisutna uvijek pa i u najobičnijim svakodnevnim aktivnostima. On je jedino po tome čovjek jer je uvijek usmjeren, na putu je prema Bogu, znao on to izričito ili ne, htio on to ili ne, on je dakle uvijek neograničena otvorenost onoga zatvorenog (ograničenog - n.a.) prema Bogu« (Karl RAHNER, Hörer des Wortes, München, 1971, 75-76).

${ }^{18} \mathrm{Ta}$ je ideja, iako nije detaljnije razrađena, prisutna već kod Tome Akvinskog: „Omnia cognoscentia cognoscunt implicite Deum in quolibet cognitio« (De Veritate, q. 22, a. 2, ad 1).

19 »Pokret (usmjerenost) duha i slobode, obzor toga pokreta nema granica. Bilo koji predmet naše svijesti nad kojim se zaustavimo, [...] samo je jedan korak, uvijek novo polazište toga pokreta koji vodi u Vječno i Bezimeno" (Karl RAHNER, Erfahrung des Heiligen Geistes. Schriften zur Theologie, sv. XIII, Einsiedeln, 1978, 226-251, 234).

${ }^{20}$ Usp. Curić, Dokazivanje Božje opstojnosti nekoć i danas..., 156.
} 


\subsection{Područje konkretnog životnog iskustva - iskustvo Sveobuhvatnog Smisla}

Pozornost refleksije usmjeravamo sada na ono iskustveno područje koje je svakom čovjeku blisko, bavio se filozofijom ili ne; a to je svakodnevni život ili svakodnevno spontano životno iskustvo.

Promatrajući svoje svakodnevno življenje u njemu razbiremo ogromno i raznoliko područje svojih svakodnevnih doživljaja, na temelju kojih polagano, s vremenom, prikupljamo životno iskustvo, na čijim temeljima onda osmišljavamo vlastiti život. Kao i u prethodnom koraku, refleksija će i ovdje biti usmjerena na analogno pitanje: može li se u ljudskoj svakodnevici pronaći nekakvo očitovanje prisutnosti Svetoga, Uzvišenoga, Boga, ili smo u traženju smisla i značenja vlastitom postojanju i djelovanju prepušteni sami sebi i slučaju?

Ono što se odmah i prilično nedvojbeno pokazuje očitim u ljudskom svakodnevnom življenju i djelovanju, i što ujedno trasira odgovor na postavljeno pitanje, jest činjenica da, bez obzira na to gdje živjeli, koje rase ili nacije bili, bez obzira na kulturu, moral i religiju kojoj pripadali, ili bilo što drugo što nas kao ljude dijeli, u jednom smo ipak svi ujedinjeni; mi kao ljudi, kao ljudska bića, živimo i drago nam je što smo živi, volimo život. Unatoč, dakle, životnim poteškoćama, koje katkada graniče s neizdrživošću, ipak se svim silama borimo sačuvati život. Očito je stoga da se naše svakodnevno životno iskustvo iskonski i intimno ravna načelom: isplati se živjeti! Ili još preciznije: život ima smisla! To jamačno upućuje na zaključak da je sveukupnost naših raznolikih svakodnevnih iskustva usmjerena i sažimlje se u jednoj jedinoj, za ljudski život ključnoj riječi: »smisao « ${ }^{21}{ }^{2}$ Čini se da upravo na pitanju »smisla« stoji i pada sav naš životni-iskustveni bitak. Bez smisla i samo postojanje, a onda i sve drugo bilo bi nepodnošljivo. I samo konkretno životno iskustvo očituje i neprestano potvrđuje da besmisao nije nikakva opcija. Od besmisla se ne može živjeti, niti u besmislu opstati: svako postojanje već je iskonski - ontološki - prožeto »smislom« i to u svakom smislu.

Kada je pak riječ o semantičkoj vrijednosti pojma »smisao«, potrebno je precizirati da tu nikako ne mislimo niti ga razumijevamo kao nekakvo subjektivno postignuće, koje bi dakle subjekt vlastitim trudom mogao sam sebi i za sebe priskrbiti, te po vlastitoj volji projicirati u stvarnost. Naprotiv, smisao razumijevamo kao objektivnu vrjednotu, koja se na poseban način očituje kroz njegov transcendentalan karakter. On, naime prethodi i normira sveukupnost ljudskih doživljaja i to na način da dominira cjelinom našega življenja, tj. iskustvenog bitka. Kad kažemo da »smisao« dominira cjelinom našeg postojanja i življenja, pod tim onda razumijevamo da on prožima sve pojedinačne fragmente našega iskustva, slažući ih u jedinstvenu cjelinu koja je shvatljiva za ljudski um i istovre-

${ }^{21}$ Usp. isto, 157-158. 
meno prihvatljiva ljudskoj volji. ${ }^{22}$ Razmotrimo stoga neke značajke »smisla« koje jamačno upućuju na njegov objektivan karakter.

Uviđamo da je »smisao«, na neki način, postavljen kao uvjet mogućnosti sveukupnog našeg djelovanja, tj. da nam na neki način prethodi. To se ogleda $u$ činjenici da tek pod pretpostavkom smisla možemo uopće nešto suvislo tvrditi ili pak postaviti neko suvislo pitanje. Štoviše, samo pod pretpostavkom smisla možemo svoje pojedine čine, pa naposljetku i samo vlastito postojanje, vlastiti život, proglasiti besmislenim.

Uočavamo nadalje da »smisao« u nama podržava nadu da ne klonemo u raznim životnim poteškoćama i razočarenjima. Time nas on podržava i održava na životu. Primjećujemo naime da naša životna perspektiva, naš životni obzor, nikada nije toliko sužen, da naše svakodnevno iskustvo nikada nije toliko zamračeno, a da se u njemu ne bi naslućivalo neugasivo svjetlo smisla.

Činjenica je, to svi, pa i ne tako rijetko, doživimo, da u teškim životnim situacijama i razočarenjima obično, i to uglavnom nesvjesno, reagiramo: »Eh, da sam ja ovaj svijet stvarao, da ja njime upravljam, ja bih napravio to i to...«. Time zapravo priznajemo da mi ipak dohvaćamo samo neznatan dio cjeline, te da, kako se često čuje, postoji neka »viša sila« koja nas u potpunosti nadilazi, koja sve vodi i upravlja, ili preciznije rečeno, koja sve »proviđa«, koja svemu daje

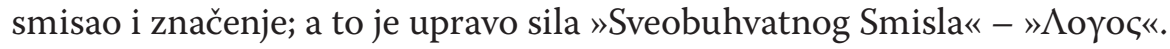

Možemo, stoga, ustvrditi da je svagdanje čovjekovo iskustvo, kroz prožetost smislom, ispunjeno uzvišenom prisutnošću Svetoga. Pod vidom životnog

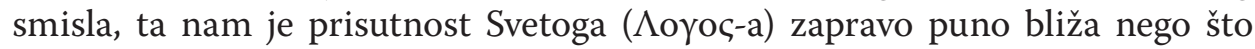
možemo uopće zamisliti: bez Smisla ne ide, htjeli mi to ili ne, sviđalo nam se to ili ne. To vrijedi za sva ljudska bića bez iznimke, bili pripadnici neke religije ili ne, slijedili ili ne neko određeno vjerovanje, smisao je ključan za čovjeka kao čovjeka, tj. vezan je za ključnu sastavnicu njegove ontološke strukture - duh.

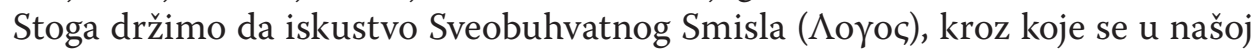
svakodnevici »objavljuje« prisutnost Svetoga, posjeduje obilježja iskonskog religioznog karaktera. ${ }^{23}$

Naposljetku utvrđujemo da je ono što se pokazalo u metafizičkim analizama kao »Punina Bitka« od kojega sva druga pojedinačna bića primaju ono što imaju i jesu; u transcendentalnom iskustvu kao ontološki »Temelj«, koji je iskonski »izvor« $\mathrm{i}$ »uvir« (Cilj) cjelokupnog ljudskog djelovanja; te u spontanom životnom iskustvu kao »Sveobuhvatni Smisao«, u čijem okrilju osmišljavamo vlastito postojanje, zapravo jedna jedinstvena i Najuzvišenija Zbilja, koju, kako to naznačuje Toma Akvinski na kraju svakog od pet puteva, svi nazivaju »Bog« ${ }^{24}$ Pokazuje se, naime, da ono što je o Božjem postojanju, na logičko-spekulativnoj - metafizičkoj - razini izraženo u silogizmima, nije igra riječi bez

\footnotetext{
${ }^{22}$ Usp. isto, 158-159.

${ }^{23}$ Usp. isto, 159-160.

${ }^{24} \gg$ Quod omnes dicunt - intelligunt, nominant - Deum« (Summa Th., I, q. 2, a. 3).
} 
sadržaja, a time i smisla i značenja, nego da ima svoje ishodište, a time i čvrstu podlogu u konkretnom životnom iskustvu koje upućuje na zbiljski sadržaj i stvarnu snagu tih dokaza.

\section{Riječ »Bog« kao plod životnog iskustva naraštaja}

Da bismo zaokružili ovo promišljanje, potrebno je još osvrnuti se ukratko na samu riječ - pojam - »Bog«. Promotrit ćemo je ovdje iz perspektive problema koji nije posve nov, ali je u novije vrijeme ponovno snažno aktualiziran. Riječ je dakle o pitanju semantičke vrijednosti riječi - pojma - Bog, a onda, na tom tragu, i opravdanosti njezine uporabe, posebno u filozofskom kontekstu, i eventualne uloge religioznog iskustva u rasvjetljavanju tog pitanja.

U suvremenoj filozofiji, na tragu logičkog pozitivizma i filozofije jezika, ali i u nekim novijim teološkim strujanjima, ponovno su aktualizirana mišljenja i stavovi koji stavljaju u pitanje značenjsku vrijednost riječi - pojma - Bog, a time i opravdanost njezine uporabe. ${ }^{25}$ Neki je autori žele zaobići, zamijeniti nekim drugim riječima ili jednostavno izostaviti.

Ipak, barem dio tih stavova i prigovora bi trebalo uzeti ozbiljnije u razmatranje, ali samo pod određenim uvjetima. No, kako će se sada vidjeti, upravo ti uvjeti obesnažuju meritum tih kritika. ${ }^{26}$

Prvi uvjet, pod kojim bi uporaba riječi »Bog« bila dvojbena, jest kad bi se tom riječi htjelo, na neki način, objektivizirati Onoga koji se u prethodnim analizama pokazao kao Najuzvišenija Zbiljnost-Punina Bitka-Temelj-Smisao. No, i metafizičke analize, ali i one svakodnevnog životnog iskustva, pokazale su da On nije samo jedan u nizu objekata naše spoznaje i iskustva, niti se njegovo postojanje dohvaća na način na koji se dohvaća njihovo. U njemu metafizička refleksija vidi Apsolut, Puninu Bitka, a transcendentalna refleksija ontološki Temelj, koji je apsolutni uvjet mogućnosti svake pojedinačne spoznaje i svakog pojedinačnog iskustva. U svakom tom pojedinačnom činu spoznaje i iskustva On se istovremeno skriva i otkriva, te kao takav u njima je uvijek prisutan, ali ne na tematski način, nego kao su-spoznat i su-iskušen.

Drugi je uvjet, kad bi se pod tim pojmom mislilo, odnosno kad bi se pretendiralo da ta riječ posve dovoljno naznačuje i izriče Puninu-Temelj-Smisao. Jasno je, naime, iz prethodnih analiza, da Najuzvišenija Zbiljnost u potpunosti nadilazi i izmiče svakom pojmu i svakom pojmovnom određenju. U tom smislu

\footnotetext{
${ }^{25}$ Daniel Dennett, jedan od predstavnika tzv. »new atheism« - »novog ateizma«, nastojeći pokazati problematičnost pristupa dokazivanju Božjeg postojanja, u svojoj kritici polazi od osporavanja same riječi - pojma - »Bog«: »The concept of God is insufficiently determinate to be possible to know what proposition is at issue in the debate over God's existence « (Daniel DENNETT, Breaking the Spell. Religion as a Natural Phenomenon, New York, 2006, 246).

${ }^{26}$ Usp. Josip ĆURIĆ, Repetitorij teodiceje (rukopis), Zagreb, 1978, 30-31.
} 
On nema imena, neizreciv je: »Ja sam koji jesam [...] Ja (naprosto - n.a.) jesam « (Izl 3, 14).

Nedvojbeno je da pri govoru o značenju i uporabi riječi »Bog«, treba voditi računa o činjenici da su sve ljudske ideje, riječi i pojmovi o »Bogu« sami po sebi nepotpuni, ograničeni ili jednostavno manjkavi. No, unatoč svim nedostatnostima i poteškoćama objektivnog karaktera, vezanim, dakle, uz ograničenja ljudske spoznaje, te transcendentnost Najuzvišenije Zbilje, koju riječ »Bog« označuje, ili na koju upućuje, a time i eventualnim bojaznima od njezinih iskrivljenih zamišljaja i predodžbi, uvjerenja smo da je neopravdano tu, kroz povijest već od davnina, pa i u filozofskom okružju, uvriježenu riječ, samo tako ukloniti iz uporabe ili je zamijeniti nekom drugom. To uvjerenje temeljimo prije svega na refleksiji o procesu nastajanja jezika. Naime, činjenica je da riječi zadobivaju značenje i vrijednost u svakodnevnom životnom iskustvu, koje ih stvara, razvija i oblikuje, a upravo je taj kontekst kod većine ljudi nepatvoren, ispravan. Nije li, u tom smislu, upravo riječ Bog kroz cijelu povijest bila čovjeku i čovječanstvu »šifra« za Najuzvišeniju Zbilju, za Onoga, koji nema imena, koji naprosto jest, za Onoga koji je »Prvi i Posljednji, Početak i Svršetak« (Otk 22, 13), šifra za »Neizrecivog«, za Onoga koji je, što god mi mogli misliti ili reći o njemu, uvijek »ưrép«? Nije li se u riječ Bog slijevalo sve religiozno iskustvo i govorenje mnoštva naraštaja kroz povijest? Kako je već naznačeno, kao i svaka druga ljudska riječ, i ova ostaje nespretna i manjkava, ali nije li i sav naš govor o Bogu uglavnom mucanje i tepanje? Nismo li i inače u svakodnevnom životu najnespretniji u izricanju najdubljih, najiskrenijih i najautentičnijih ljudskih iskustva i doživljaja kao što su poštovanje i ljubav? Držimo stoga da jednostavna riječ »Bog«, koju je iznjedrilo samo životno iskustvo, nije neprikladna, pa ni u filozofskoj refleksiji, da bi u njoj sricali i njome označavali »Najuzvišeniju Zbiljnost« Puninu-Temelj-Smisao. ${ }^{27}$

\section{Zaključak}

U nekoliko točaka izdvojit ćemo osnovne postavke i uvide do kojih se došlo u radu.

Kad je riječ o pristupu tradicionalnim dokazima za Božje postojanje, strukturiranim na pojmovima i načelima klasične metafizike, želi li se sačuvati njihova sadržajna vrijednost, a time i filozofska relevantnost, držimo da bi, kao nezaobilazan korak $\mathrm{u}$ tom smjeru, trebalo ozbiljno uzimati u obzir kritike na račun metafizike. Da su osporavanja metafizike ujedno i osporavanja racionalnog dokazivanja Božjeg postojanja, jasno je već i iz Kantovih postavki o nemogućnosti metafizike kao znanosti, a time i spekulativnog dokazivanja Božjeg

${ }^{27}$ Usp. isto, 31. 
postojanja. S druge pak strane, ako je u klasičnim metafizičkim paradigmama zaista »zanemaren « subjekt i »zaboravljen« bitak, kako to tvrdi suvremena kritika, onda dokazi koji su na njima izvedeni uistinu ne posjeduju zbiljski sadržaj, niti stvarnu snagu.

Slijedeći Maréchalovu metodu transcendentalne refleksije pokazali smo da je »bitak« u metafizici Tome Akvinskog - autentično tumačen kao actus essen$d i$ - iskonski apriorni uvjet mogućnosti postojanja, a onda spoznaje i iskustva. Bitak, kao actus essendi, po kojemu svako pojedinačno biće bivstvuje, tragom svoga utemeljenja, upućuje na Puninu Bitka, tj. na Onoga koji je Ipsum Esse. Taj pak Bitak, koji se u iskustvu objavio kao Temelj i Smisao, jest a priori u apsolutnom smislu, tj. apsolutni uvjet mogućnosti svakog postojanja, a time i spoznaje i iskustva. Stoga možemo ustvrditi da u svakom pojedinačnom susretu ljudskog duha sa stvarnošću, na neki način, imamo su-spoznaju i su-iskustvo Punine-Temelja-Smisla i u svakoj pojedinačnoj afirmaciji ujedno suafirmiramo i Temelj, kao uvjet mogućnosti svake afirmacije.

Uvide do kojih se došlo u metafizičkoj refleksiji, u drugom dijelu rasprave promišljalo se i analiziralo iz perspektive konkretnoga životnog iskustva. U tim je analizama pokazano da je iskustvo, na koje upućuje transcendentalna refleksija, a na čijoj se najdubljoj razini »dohvaća «emelj-Smisao, iskonski neodvojiv dio sveukupnosti onoga primarnog i izravnog ljudskog doživljaja. Štoviše, pokazano je da je ono intimno utkano u same temelje ljudskoga spontanog životnog iskustva koje, kao uvjet mogućnosti, prethodi svakom iskustvu, ali i svakoj filozofskoj refleksiji, uključujući i onu metafizičku, ključnu za dokazivanje Božjega postojanja, te da kao takvo posjeduje obilježja autentičnoga religioznog karaktera

U analizama je također izašla na vidjelo specifičnost religioznog iskustva na koje upućuje transcendentalna refleksija. Ona se očituje u činjenici da taj vidik religioznog iskustva nije samo privilegij ljudi koji pripadaju nekoj religiji ili slijede neko vjerovanje, ili je dohvatljivo samo određenima, tj. odabranim pojedincima, nego je, kao što su to i dokazi, dohvatljivo čovjeku kao čovjeku, tj. vezano je uz ključnu sastavnicu ljudske ontološke strukture, a to je duh - i to upravo u smislu Rahnerove tvrdnje:

»Čovjek je duh, tj. živi svoj život u neprestanoj otvorenosti prema Bogu. [...] On je jedino po tome čovjek jer je već iskonski usmjeren prema Bogu, znao on to izričito ili ne, htio on to ili ne... $\ll^{28}$

Može se stoga ustvrditi da transcendentalno-refleksivni pristup:

a) vodeći računa o kritikama, otvara nov prostor metafizici, odnosno »rehabilitira« metafiziku bitka upućujući na stvarni sadržaj njezinih pojmova i načela, što je ponovno čini čvrstim temeljem u strukturi tradicionalnih dokaza za Božje postojanje;

\footnotetext{
${ }^{28}$ Rahner, Hörer des Wortes..., 75.
} 
b) očituje iskonsko jedinstvo metafizičkih izvoda, posebice onih koji se odnose na bitak shvaćen kao actus essendi, a onda i na Ipsum Esse (TotalitetPuninu), s onima na koje upućuju analize konkretnog ljudskog životnog iskustva, a koji su artikulirani kroz termine: $» T e m e l j « \mathrm{i} »$ Sveobuhvatni Smisao«;

c) pokazuje kako je u same temelje spontanog ljudskog životnog iskustva intimno utkana religiozna crta koja teoretskim dokazima, uobličenim u logičke silogizme, daje zbiljski iskustveni sadržaj, a time i stvarnu snagu naspram kritika.

Na tom tragu držimo opravdanim zaključiti da, ako se želi da klasični dokazi i danas imaju željenu snagu i filozofsku relevantnost, uz, na tragu transcendentalne refleksije, »oživotvorenu « metafiziku, religiozno iskustvo, promatrano iz iste perspektive, trebalo bi biti percipirano i uzimano, upravo onako kako se u analizama i pokazalo; kao autentičan "prirodni« kontekst, a time i kao nezaobilazna referentna točka u pristupu dokazima, tj. u njihovom promišljanju, proučavanju i poučavanju: »Bez njega« - kako tvrdi J. Curić - »i sama riječ Bog, neće nam puno značiti, a i sami logičko-spekulativni dokazi o Bogu neće nas daleko dovesti. « ${ }^{29}$

${ }^{29}$ Ćurić, Dokazivanje Božje opstojnosti nekoć i danas..., 153. 
Anto Pavlović* - Stjepan Štivić**

Religious experience from the perspective of transcendental reflexion and its role towards the criticism of metaphysics and the arguments for the existence of God

\section{Summary}

Is it still philosophically sustainable to approach the traditional arguments for the existence of God in such a way that even the criticism questioning the metaphysics, and with that the very arguments, is not taken into account, as well as some form of religious experience opposing the criticism? This article discusses these questions, bringing and analyzing some insights that we believe can contribute to the shortcomings of such approach. We try to give our specific perspective, which we call transcendental-reflexive according to its philosophical foundation. We try to present how such perspective can give a different view on classical metaphysics and therefore on arguments for the existence of God. And also show that religious trait is essentially and intimately interwoven in the very grounds of spontaneous human life experience through co-experience of the Totality-the Foundation and of the All Meaning - which gives metaphysics as well as the traditional arguments, based on its categories a true content and strength towards criticism. Our analyses present also the specific nature of religious experience shown by the transcendental reflexion. It is not exclusively a privilege of people, who are religious, or who belong to a religious believe or group, it is a trait of people as human beings, related to their spiritual (rational) ontological structure.

Key words: metaphysics, arguments for the existence of God, transcendental reflexion, life experience, religious experience.

(na engl. prev. Anto Pavlović)

\footnotetext{
* Anto Pavlović, PhD, Assist. Prof., Faculty of Philosophy and Religious Studies, University of Zagreb; Address: Jordanovac 110, pp 169, HR-10000 Zagreb, Croatia; E-mail: apavlovic2010@ gmail.com.

** Stjepan Štivić, MPhil, PhD candidate at the Faculty of Philosophy and Religious Studies, University of Zagreb; Address: Jordanovac 110, HR-10000 Zagreb, Croatia; E-mail: stjepan.stivic@ gmail.com.
} 